\author{
Paulina Nowak-Korcz \\ Katedra Języków Specjalistycznych \\ oraz Komunikacji Międzykulturowej \\ Uniwersytet Łódzki \\ paulina.nowak-korcz@uni.lodz.pl
}

\title{
MAKROSTRUKTURA TEKSTÓW ORZECZEŃ SĄDOWYCH NA PRZYKŁADZIE POLSKICH I FRANCUSKICH WYROKÓW
}

\section{Wstęp}

W niniejszym artykule analizie porównawczej poddane zostały teksty polskich i francuskich orzeczeń sądowych: wyroki z zakresu prawa cywilnego ${ }^{1}$ w ujęciu translatologicznym.

W kontekście przekładu sądowego - sięgając do typologii tekstów z dziedziny prawa (Gajda 2004: 28, za: Jopek-Bosiacka 2006: 210) - analizowane teksty wyroków określa się jako „teksty sądowe”. Utworzono je w języku prawniczym praktyki orzeczniczej, w którym formułowane są rezultaty postępowań sądowych lub ich uzasadnienia (Zieliński 1999: 64). Są ponadto „decyzjami wydawanymi przez sąd, zawierającymi rozstrzygnięcia merytoryczne co do istoty danej sprawy $[\ldots]$ są wypowiedziami produktywnymi, mają moc obowiązującą" (Lizisowa 2016: 108). Należy podkreślić, że polskie i francuskie teksty wyroków sądowych, mimo iż są zakorzenione w kulturze prawa

${ }^{1}$ Pod pojęciem „orzeczeń sądowych” rozumie się wszelkie decyzje sądu. Sądy, zarówno w postępowaniu cywilnym, jak i karnym wydają orzeczenia w postaci wyroku lub postanowienia. Jeżeli nie jest wymagane wydanie wyroku, sąd wydaje postanowienie. W sprawach mniejszej wagi sędziowie wydają zarządzenia. Termin „orzeczenie sądowe" pozostaje zatem w stosunku do pozostałych terminów w relacji hiperonim - hiponim. Podobnie francuska terminologia prawnicza obejmuje globalnie kategorię orzeczeń sądowych i posługuje się określeniem décision de justice (Machowska, Wojtyczek 2004: 235). W zakresie kategorii orzeczeń określanych jako décision de justice mieszczą się zatem jugement, arrêt et ordonnances. 
kontynentalnego, różnią się znacznie zarówno na poziomie globalnej, graficznej struktury tekstu, jak i na poziomie jednostek leksykalnych czy gramatycznych.

Celem niniejszego artykułu jest analiza podobieństw i różnic wyłącznie na wspomnianym poziomie makrostruktury polskich i francuskich wyroków sądowych z zakresu prawa cywilnego oraz wskazanie na istotne znaczenie organizacji graficznej tekstu w procesie przekładu. Analiza tego typu w aspekcie translatologicznym jest niezwykle istotna, gdyż dostarcza niezbędnych w thumaczeniu konotatów formalno-tekstowych.

$\mathrm{W}$ badaniach wykorzystano analizę tekstów porównywalnych ${ }^{2}$. Zastosowano również model pragmatycznego tłumaczenia terminów prawnych zaproponowany przez Kierzkowską (2002). Ponadto bazowano na obserwacji empirycznej struktur typowych dla orzeczeń polskich i francuskich. Korpus wyroków składa się z tekstów pochodzących ze źródeł własnych autorki³. Przykłady polskich uzasadnień pobrano za pośrednictwem Portalu Orzeczeń Sądów Powszechnych ${ }^{4}$.

2 Teksty porównywalne należy odróżnić od tekstów paralelnych. W badaniach korpusowych za teksty porównywalne uważa się teksty oryginalne w przynajmniej dwóch językach, posiadające ściśle określone cechy wspólne. Matulewska (2010: 57) podkreśla rolę tekstów porównywalnych: „z punktu widzenia przekładu najbardziej wiarygodnym źródłem informacji terminologicznej i tekstowo-normatywnej są zawsze teksty tego pierwszego rodzaju (porównywalne)”. Teksty te stanowią źródło cennych wyrażeń, sformułowań oraz związków idiomatycznych, które można wykorzystać w tłumaczeniu (Kubacki 2013: 146). Za tekst paralelny uważany jest natomiast „tekst w języku docelowym, należący do tego samego gatunku, co tekst wyjściowy i/lub traktujący o tej samej problematyce, z którego tłumacz może wynotować terminy, wyrażenia i wiadomości tematyczne, których potrzebuje, aby dokonać tłumaczenia. [...] teksty paralelne są dla tłumacza źródłem właściwych słów, terminologii, informacji o charakterze stylistycznym, mogą one również ułatwić mu zrozumienie tekstu wyjściowego" (Delisle 2006: 97). Doniosłą rolę znajomości oraz umiejętności eksploracji tekstów paralelnych jako niezbędnych i niezwykle pomocnych narzędzi w tłumaczeniu specjalistycznym i prawniczym akcentują ponadto m.in. Kielar (1991), Kierzkowska (2002), Gortych-Michalak (2013), Neubert (1996).

${ }^{3}$ Warto wspomnieć, że obecnie na rynku polskim istnieje wiele opracowań, zawierających wzory dokumentów do tłumaczeń, w tym wzory wyroków np.: B. Bosek-Szeska, A. Michalska (2011), Nouveau Receuil de documents français, Wydawnictwo Translegis, Warszawa; Z. Rybińska (2011), Teksty egzaminacyjne dla kandydatów na thumacza przysięglego, Wydawnictwo Translegis, Warszawa; B. Cieślik, L. Laska, M. Rojewski (2010), Egzamin na tlumacza przysiegłego. Komentarz, teksty egzaminacyjne, dokumenty, Wydawnictwo C.H. Beck, Warszawa.

${ }^{4}$ Zob. www.orzeczenia.ms.gov.pl (dostęp: 26.07.2020). 


\section{Makrostruktura wyroków sądowych w prawie polskim i francuskim}

Zarówno polskie, jak i francuskie wyroki sądowe muszą zawierać ściśle określone elementy, które warunkują ich makrostrukturę. Zgodnie z art. $325 \mathrm{KPC}$ :

Sentencja wyroku powinna zawierać wymienienie sądu, sędziów, protokolanta oraz prokuratora, jeżeli brał udział w sprawie, datę i miejsce rozpoznania sprawy i wydania wyroku, wymienienie stron i oznaczenie przedmiotu sprawy oraz rozstrzygnięcie sądu o żądaniach stron ${ }^{6}$.

Podobnie francuski Kodeks postępowania cywilnego (art. 454) ${ }^{7}$ wskazuje, że wyrok powinien być wydawany w imieniu narodu francuskiego i zawierać: oznaczenie sądu wydającego wyrok oraz nazwiska sędziów; datę sporządzenia wyroku; nazwisko prokuratora, jeśli był obecny na rozprawie; nazwisko sekretarza; oznaczenia stron, miejsce ich zamieszkania oraz siedziby; nazwiska adwokatów lub innych osób, jeśli występowały w sprawie; w postępowaniu niespornym oznaczenie osób, którym orzeczenie doręcza się. Elementy są zatem takie same, a pominięcie któregoś z nich lub niedokładność $\mathrm{w}$ ich stosowaniu może skutkować nieważnością orzeczenia (zob. Machowska, Wojtyczek 2004: 238).

W makrostrukturze polskich wyroków sądowych można wyróżnić dwie części: (i) sentencję (treść wyroku) oraz (ii) uzasadnienie. W sentencji (art. 325 KPC) zaś można wyróżnić część stałą, zwaną rubrum (inaczej komparycją) oraz część zmienną - tenor (formulę sentencji), zawierającą rozstrzygnięcie o żądaniach stron (zob. Dolecki 2006: 206; Studzińska, Cioch 2017: 398). Pod sentencją wyroku znajdują się podpisy wszystkich członków składu orzekającego. To właśnie sentencja jest najczęściej przekładana przez tłumaczy.

W rubrum (TLOT: le chapeau) podawane są: sygnatura akt sprawy, nagłówek, data i miejsce wydania wyroku, oznaczenie sądu i wydziału, w którym zapadł wyrok, nazwiska członków składu orzekającego oraz protokolanta, wskazanie prokuratora, jeśli brał udział w sprawie, data i miejsce rozpoznania sprawy oraz rodzaj posiedzenia, oznaczenie stron, oznaczenie przedmiotu

${ }^{5}$ Zob. Lizisowa (2013: 32): „makrostruktura reprezentuje temat globalny tekstu, a także obejmuje globalną organizację treści. Natomiast mikrostruktura stanowi rodzaj schematu segmentów tekstowych, którym przypisuje się skonwencjonalizowane kategorie tekstowe $[\ldots]$ ".

${ }^{6}$ https://www.lexlege.pl/kpc/art-325/ (dostęp: 26.07.2020).

7 Zob.https://www.legifrance.gouv.fr/affichCodeArticle.do?idArticle=LEGIAR TI000006410700\&cidTexte=LEGITEXT000006070716 (dostęp: 26.07.2020). 
sprawy. W nagłówku rubrum wyroku zamieszcza się sformułowanie „W imieniu Rzeczypospolitej Polskiej” poprzedzone wizerunkiem godła państwowego.

Tenor (TLOT: le dispositif) zawiera rozstrzygnięcie sądu o żądaniach stron, postanowienia dodatkowe oraz orzeczenie o kosztach postępowania. Część zawierająca tenor powinna być zredagowana w taki sposób, aby realizacja wyroku mogła być dokonana na podstawie samej treści sentencji, bez potrzeby dokonywania wykładni (Dolecki 2006: 207). Ogłoszenie wyroku dokonuje się przez odczytanie sentencji i ustne podanie powodów rozstrzygnięcia. Z kolei uzasadnienie sąd sporządza pisemnie na wniosek strony o doręczenie wyroku $\mathrm{z}$ uzasadnieniem, zgłoszony $\mathrm{w}$ terminie tygodniowym od dnia ogłoszenia sentencji wyroku (art. $328 \mathrm{KPC})^{8}$. Przykład sentencji w języku polskim przedstawiono poniżej:

Tabela 1. Makrostruktura polskiego wyroku

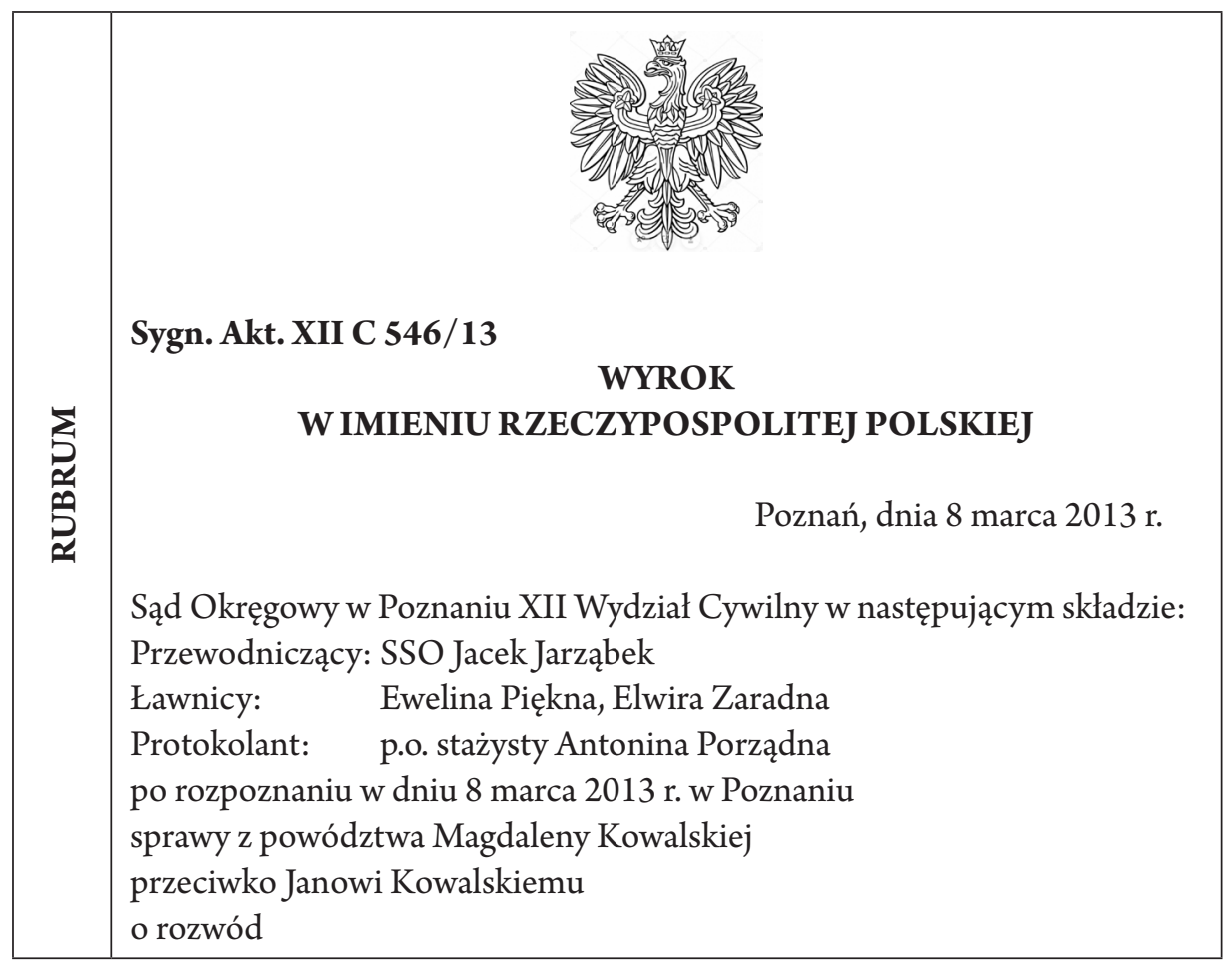

${ }^{8}$ Ma to istotne konsekwencje w kwestii uprawomocnienia się wyroku. Jeżeli strona nie wniesie o sporządzenie uzasadnienia wyroku, wyrok uprawomocni się znacznie szybciej. W uzasadnieniu sąd wyjaśnia podstawy faktyczne i prawne wyroku. 


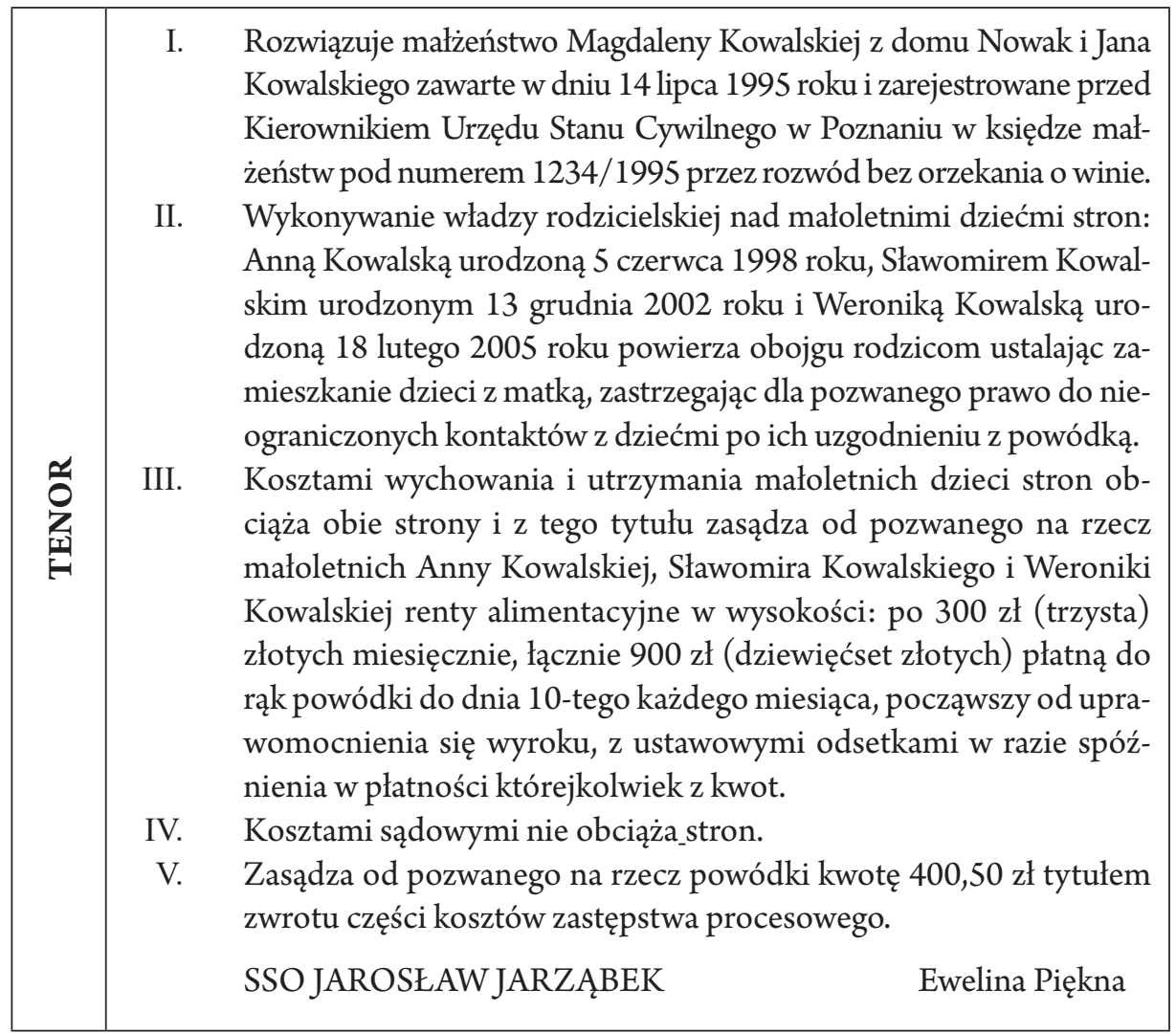

Źródło: opracowanie własne PNK.

Z kolei w makrostrukturze francuskich wyroków można wyróżnić cztery zasadnicze części (Flöter-Durr, Nowak-Korcz 2018):

a) Le chapeau - część zawierającą stałe elementy wstępne wskazane $\mathrm{w}$ art. $454 \mathrm{CPC}$;

b) La partie descriptive (l'exposé du litige) - część opisową, zawierającą przytoczenie i ustalenie faktów oraz roszczenia stron i podstawy prawne;

c) La partie démonstrative (les motifs du jugement, motifs de la décision, motifs) - część dowodową, zawierającą uzasadnienie wyroku, przedstawiającą sposób rozumowania sądu, rozważania sądu odnośnie analizowanych faktów oraz argumenty, na których się oparł przy wydawaniu wyroku;

d) Le dispositif (l'énoncé de la décision concernant la prétention) - część stanowiącą decyzję sądu, rozstrzygnięcie sporu (art. 455 CPC) ${ }^{9}$.

9 Zob. https://www.legifrance.gouv.fr/affichCodeArticle.do?idArticle=LEGIA RTI000006410706\& cidTexte $=$ LEGITEXT000006070716\&dateTexte $=19990301$ (dostęp: 26.07.2020). 
Francuskie wyroki zawierają takie same elementy wstępne, co wyroki polskie (sygnaturę akt, datę wydania wyroku, nagłówek, oznaczenie sądu i składu sędziowskiego, oznaczenie stron procesowych i ich pełnomocników oraz inwokację „au nom du peuple français” - zob. Żołnierczyk 2017: 1), chociaż ich kolejność nie jest taka sama. W następnych częściach struktura wyroku francuskiego również odbiega od struktury polskiego wyroku. W polskich wyrokach następuje $\mathrm{w}$ tej części rozstrzygnięcie, a dopiero potem uzasadnienie stanowiska sądu (pod warunkiem, że strona złoży wniosek o pisemne uzasadnienie). Z kolei w wyrokach francuskich, odwrotnie, najpierw przytaczane są motywy, czyli obligatoryjne uzasadnienie sporządzane z urzędu (motifs de la décision) (Machowska, Wojtyczek 2004: 237), a następnie przedstawione jest rozstrzygnięcie (tzw. dispositif, czyli formuła sentencji), które jest jego integralną częścią. Poniżej przedstawiono przykład makrostruktury francuskiego wyroku.

Tabela 2. Makrostruktura francuskiego wyroku (TGI)

\begin{tabular}{|c|c|}
\hline & 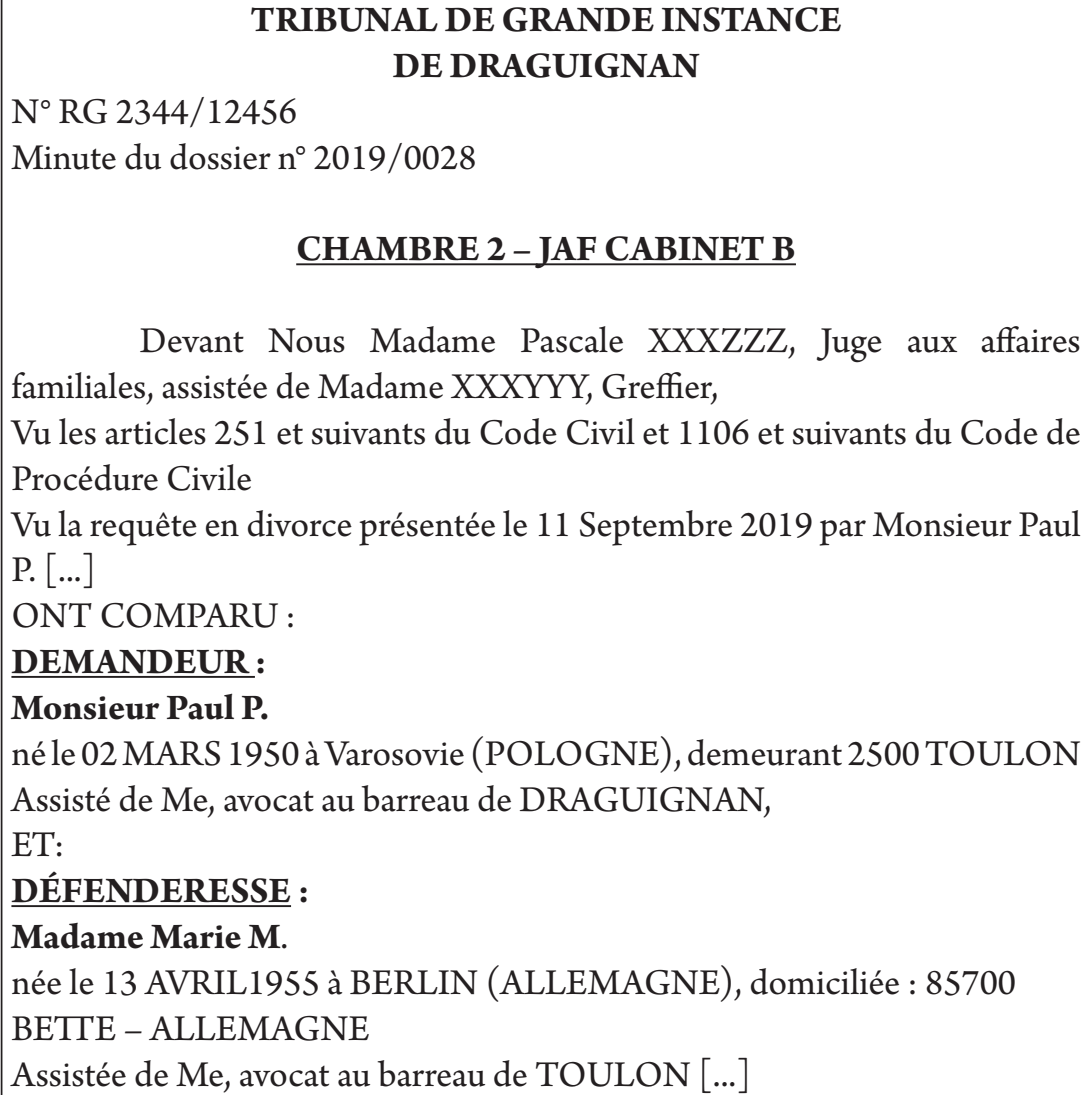 \\
\hline
\end{tabular}




\begin{tabular}{|c|c|}
\hline 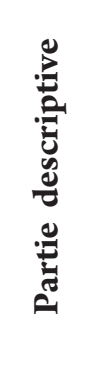 & $\begin{array}{l}\text { EXPOSÉ DU LITIGE } \\
\text { Mme Marie M. [...] et Mr Paul P. [...] se sont mariés le } 5 \text { mars } 1987 \text { devant } \\
\text { l'officier de l'état-civil de la commune de Miami, Etat de Floride, USA, Deux } \\
\text { enfants sont issus de cette union, aujourd'hui majeurs et autonomes : } \\
\qquad \begin{array}{l}\text { Ingrid née le } 12 \text { mars } 1989 \\
\text { Patricia née le } 13 \text { juillet } 1992\end{array} \\
\begin{array}{l}\text { Le } 14 \text { septembre 2019, Mr Paul P. a déposé au greffe une requête en divorce } \\
\text { sur le fondement de l'article } 251 \text { du code civil. }\end{array}\end{array}$ \\
\hline 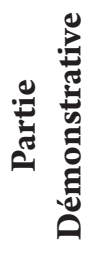 & $\begin{array}{l}\text { MOTIFS DE LA DÉCISION } \\
\text { Sur la recevabilité des attestations: }[\ldots] \\
\text { Sur les mesures entre les époux: }[\ldots] \\
\text { Sur l'attribution de la jouissance du domicile conjugal et du mobilier du } \\
\text { ménage }[\ldots]\end{array}$ \\
\hline 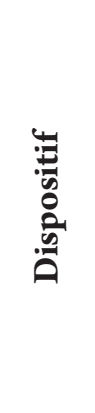 & $\begin{array}{l}\text { PAR CES MOTIFS, } \\
\text { Statuant en chambre du conseil, par ordonnance, susceptible d'appel, } \\
\text { Vu les articles } 233 \text { et } 252 \text { et suivants du code civil et l'article } 1123 \text { du code } \\
\text { de procédure civile ; } \\
\text { AUTORISONS l'époux demandeur à introduire l'instance pour que le juge } \\
\text { prononce le divorce et statue sur ses effets, (...) } \\
\text { Statuant sur les mesures provisoires, } \\
\text { CONSTATONS la résidence séparée des époux (...) } \\
\text { LE GREFFIER }\end{array}$ \\
\hline
\end{tabular}

Źródło: opracowanie własne PNK i Flöter-Durr (2020).

\section{Makrostruktura wyroków sądowych a trudności przekładowe}

Przedstawiona makrostruktura polskich i francuskich wyroków sądowych pozwala zauważyć, że znajomość struktury graficznej tłumaczonego tekstu i wyrażeń wprowadzających poszczególne jego części ma istotne znaczenie w procesie przekładu.

Przytaczanie motywów w wyrokach francuskich przed przedstawieniem rozstrzygnięcia warunkuje szczególny styl i strukturę tych dokumentów. Poszczególne argumenty uzasadnienia $w$ wyrokach francuskich wprowadzane są w oddzielnych zdaniach, zaczynających się każdorazowo od nowego akapitu, zwykle od wyrażeń typu: Attendu que..., Considérant que..., Vu...Vu que... („Zważywszy, że...”; „Z uwagi na to, że...”; „Uwzględniając...”), bądź też niekiedy formami archaicznymi typu: oui... („po wystuchaniu stron...”). Poniżej 
zaprezentowano przykład takich wyrażeń wprowadzających motywy wraz z tłumaczeniem na język polski:

\section{Przykład 1.}

$V u$ les articles 251 du Code Civile et 1106 du Code de la Procédure Civile

$V u$ la requête en divorce présentée le 14 Septembre 2017 par XY...

(Uwzględniając artykuły 251 Kodeksu cywilnego oraz 1106 Kodeksu postępowania cywilnego

Uwzględniając pozew o rozwód złożony dnia 14 września 2017 roku przez XY...)

Zgodnie ze schematem wprowadzania motywów w wyroku francuskim, po elementach wstępnych (w części opisowej) mieści się część rozpoczynająca się od tzw. exposé du litige, w której sąd ustala fakty, roszczenia stron oraz wskazuje podstawy prawne. Następnie w części dowodowej, tzw. motifs de la décision, sąd przedstawia tok rozumowania, proces dochodzenia do ustaleń faktycznych, analizując motywy oraz przedstawiając argumenty stron, na których się oparł przy wydawaniu wyroku. Jest to część, którą można przyrównać do polskiego uzasadnienia. Poza wspomnianymi wcześniej, wyrażenia typowe dla tej części to: Sur le fond... („Jeśli chodzi o kwestie merytoryczne...”); Sur la loi applicable... („W zakresie stosowanego prawa...”). Podobnie jak wspomniane Attendu que..., czy $V u$ que... wprowadzają one każdorazowo, od nowego akapitu, rozważania sądu. Dzielą ponadto tekst na części, opatrzone nagłówkiem odwołującym się do kwestii, jaką analizuje sąd zaczynającym się od przyimka Sur... Jednocześnie organizują tekst w większe fragmenty, zawierające rozważania sądu na temat kilku analizowanych motywów. Poniżej zaprezentowano przykład tego typu wyrażenia wraz z tłumaczeniem na język polski:

\section{Przykład 2.}

SUR LES CONSÉQUENCES DU DIVORCE

À l'égard des époux

Sur l'usage du nom marital

(UZASADNIENIE WYROKU W ZAKRESIE SKUTKÓW ROZWODU

W zakresie małżonków

W kwestii używania nazwiska małżonka)

W kolejnej części francuskiego wyroku (po przytoczeniu motywów i uzasadnienia) następuje właściwa formuła sentencji, zawierająca rozstrzygnięcie, czyli dispositif, który można uznać z kolei za odpowiednik polskiego tenoru. Charakterystycznymi zwrotami dla tej części są wyrażenia wprowadzające typu: Par ces motifs... Le tribunal statuant... („Z powyższych względów...”, „W związku z powyższym ...”, „Zważywszy argumenty stron...”). 
Wyrażenia charakterystyczne dla każdej z wymienionych części pokazują, że orzeczenia sądowe zawierają pewien inwentarz sformułowań właściwych tylko dla tego gatunku tekstów. Są to stałe struktury i skostniałe wyrażenia idiomatyczne, które mają określone znaczenie kontekstowe, którego niestety nie da się ustalić, korzystając jedynie ze słowników specjalistycznych, gdyż decydujące jest tu użycie i znaczenie kontekstowe tych wyrażeń. Teksty wyroków francuskich mogą zatem stanowić cenne źródło w odnajdywaniu właściwych ekwiwalentów kontekstowych w tłumaczeniu. Poniżej zaprezentowano przykłady formuł zawierających rozstrzygnięcie z orzeczeń francuskich wraz z thumaczeniem na język polski:

\section{Przykład 3.}

PAR CES MOTIFS

Le Tribunal

Statutant par jugement contradictoire;

$V u$ l'ordonnance du 5 mai 1989 ayant autorisé les époux à résider séparément

Prononce aux torts partagés le divorce de $\mathrm{X}$ et $\mathrm{Y}(\ldots)$

\section{(Z POWYŻSZYCH WZGLĘDÓW}

Sąd

Rozstrzygając sprawę wyrokiem kontradyktoryjnym;

Zważywszy postanowienie z dnia 5 maja 1989 zezwalające małżonkom zamieszkać osobno;

Orzeka z winy obojga małżonków X i Y, rozwód ...)

Porównując makrostruktury polskich i francuskich wyroków, można szybko zauważyć, że najistotniejsze różnice warunkujące strukturę wyroków dotyczą uzasadniania, a zwłaszcza struktury wprowadzania argumentacji.

W systemie francuskim wyroki zawierają najpierw uzasadnienie, czyli przedstawienie przesłanek faktycznych i prawnych, a dopiero na końcu sentencję rozstrzygnięcia (Castillo-Wyszogrodzka 2015: 481). Można tu odwołać się do metody uzasadnień zwartych, asertorycznych, „stwierdzających”, niepodejmujących zbędnych polemik, stanowiących odzwierciedlenie monteskiuszowskiej metody logiczno-sylogistycznej, materializującej ideę sądu jako bouche de la loi, czyli „ust ustawy” (Gudowski 2015: 244-245; Cornu 2005: 352). Argumenty (motywy) wprowadzane są zatem jednym bardzo długim zdaniem, zajmującym często kilka stron, rozpoczynającym się od imiesłowu „zważywszy”, stanowiącym wieloskładnikową konstrukcję zdań pojedynczych bądź złożonych, zespolonych spójnikami „że” i jednocześnie oddzielonych średnikami oraz akapitami, a niekiedy też wyróżnionych punktacją. Każdy z akapitów to przesłanka sylogizmu, „zwieńczonego konkluzją logiczną bądź jurysdykcyjną, będącą zarazem 
pointą uzasadnienia" (Gudowski 2015: 245). Reasumując, sentencja francuskiego wyroku znajduje się na końcu wyroku jako logiczny wynik, co można przyrównać do stylu biegłych, którzy wynik rozwijają ze stanu faktycznego (Krzysztoforska-Weisswasser 2010: 2; David 2002: 113). Z punktu widzenia tłumaczenia to właśnie ta struktura wyroku francuskiego stanowi największą trudność w tłumaczeniu, gdyż wiąże się z koniecznością zastosowania dużej liczby konstrukcji imiesłowowych w języku polskim, zaburzając jej przejrzystość. Niemniej niektórzy teoretycy przekładu postulują, że poprzez wprowadzenie każdego argumentu odpowiednim wyrażeniem spójnikowym, w oddzielnym zdaniu, uzyskuje się pewnego rodzaju „wyrazistość rozumowania” (Żołnierczyk 2017: 1). Ponadto stosowany system połączeń, odpowiednia interpunkcja oraz użycie wielkich liter organizuje tekst i ułatwia jego zrozumienie (zob. Šarčević 2000: 124). Warto podkreślić, że w orzeczeniach francuskich treść opatrzona jest niekiedy nagłówkami, czasami ponumerowanymi, które organizują tekst w sposób logiczny i ułatwiają odnalezienie konkretnych informacji, tak jak przykładowo: 1. Les faits de la cause („Stan faktyczny sprawy”) czy też 2 . La procédure de première instance („Postępowanie przed sądem $\mathrm{w}$ pierwszej instancji”) $\mathrm{w}$ orzeczeniach wydawanych przez Cour d’appel, czyli Sąd Apelacyjny.

Polski wyrok ma odmienne cechy w aspekcie jego uzasadniania i przytaczania argumentów. Przede wszystkim uzasadnienie nie stanowi w strukturze sentencji wyroku, integralnej, fizycznie wyodrębnionej części, gdyż sąd nie ma obowiązku przedstawiania motywów pisemnych, a jedynie $\mathrm{w}$ formie ustnej. W związku z tym wyrok z uzasadnieniem $\mathrm{w}$ formie pisemnej sporządza się i doręcza stronie, która w terminie tygodniowym od ogłoszenia sentencji złożyła wniosek o jego doręczenie (art. $328 \mathrm{KPC}$ ). Polskie uzasadnienia są, poza tym, dużo bardziej obszerne, bazują na metodzie dyskursywnej, i w odróżnieniu do uzasadnień francuskich opierają się na przedstawieniu raczej „wyjaśnień” aniżeli „stwierdzeń” uporządkowanych za pomocą tzw. Attendus czy Considérants. $\mathrm{W}$ ich strukturze wynik znajduje się więc na początku łańcucha argumentacyjnego, a uzasadnienie następuje później (zob. Krzysztoforska-Weisswasser 1995: 2-5), zaś styl wynika $\mathrm{w}$ dużej mierze $\mathrm{z}$ ugruntowania $\mathrm{w}$ tradycji niemieckiej i austriackiej (zob. Gudowski 2015: 245). Przedstawione są w nich zatem obszerna wykładnia i argumentacja, a niejednokrotnie także szerokie perspektywy rozwiązania analizowanej spornej kwestii. Zgodnie z art. 328 \$ 2 KPC polskie uzasadnienie wyroku powinno zawierać wskazanie podstawy faktycznej rozstrzygnięcia, a mianowicie: ustalenie faktów, które sąd uznał za udowodnione; ustalenie dowodów, na których się opart i przyczyn, dla których innym dowodom odmówił wiarygodności i mocy dowodowej; oraz wyjaśnienie podstawy prawnej wyroku z przytoczeniem przepisów prawa. 
Pod względem graficznym struktura polskich uzasadnień nastręcza tłumaczom wiele trudności. Swoisty monolog sądu, brak jakiegokolwiek wyodrębnienia graficznego poszczególnych części, skomplikowane, długie zdania wielokrotnie złożone stanowią nie lada wyzwanie dla tłumacza. Problematyczna z punktu widzenia praktyki translatorskiej jest także „hybrydowość” uzasadnienia nawiązującego z jednej strony do języka procedury cywilnej, karnej czy administracyjnej, z drugiej zaś - zawierającego słownictwo języka potocznego, zrozumiałe dla zwykłego obywatela (zob. Jopek-Bosiacka 2006: 210) oraz uwidaczniająca się intertekstualność, przejawiająca się w formie cytatów z ustaw, zeznań świadków, opinii ekspertów czy też odwołań do innych wyroków. Tłumacz ma do czynienia ze skomplikowaną strukturą, zawiłymi zdaniami, często naszpikowanymi mnogością dat, zbędnych liczb, numerów pism, akt itp., co znacznie utrudnia zrozumienie tekstu, nie wspominając już o spełnianiu wymogów jasności, przejrzystości stawianych uzasadnieniom ${ }^{10}$.

Przykład makrostruktury polskiego uzasadnienia przedstawiono poniżej ${ }^{11}$ :

Tabela 3. Makrostruktura polskiego uzasadnienia

\section{Streszczenie wniesienia powoda (L'exposé des faits et des demandes du demandeur)}

W dniu 28 lipca 2015 r. powód R.B. wniósł pozew przeciwko małoletniemu O.B. (1) działającemu przez matkę P M. (1) o obniżenie alimentów ... W uzasadnieniu pozwu wskazał, że ... [...]

Opis stanu faktycznego sprawy, ustalony przed sądem na podstawie dowodów nie kwestionowanych przez strony z powotaniem się na przepisy ustawy (Les faits établis sur la base des preuves non contestées par les parties en référence aux dispositions de la loi)

Sąd ustalił, co następuje:

Pozwany małoletni O.B. (1) urodzony (...) pochodzi z nieformalnego związku powoda R.B. i P.M. (1) ........Dotychczas stosunek alimentacyjny uregulowany był w drodze ugody zawartej przed Sądem Rejonowym w. T. w dniu ...... ... ]

10 Por. z postulatami wypływającymi z art. $328 \$ 2$ KPC oraz $\$ 96$ ust. 3 Regulaminu Sądu Najwyższego (zob. Gudowski 2015: 247).

${ }^{11}$ Na potrzeby niniejszego artykułu w przedstawionym przykładzie uzasadnienia polskiego w celu lepszego zobrazowania struktury wyodrębniono poszczególne jego części, stosując nagłówki zapisane kursywą. $\mathrm{W}$ oryginałach uzasadnień tekst pisany jest ciągiem i nie zawiera tego typu nagłówków, co utrudnia jego zrozumienie. 
Tabela 3 (cd.)

\section{Stanowisko sądu w sprawie (Le raisonnement du tribunal dans l'affaire)}

Sąd zważyt, co następuje:

Przedstawiony stan faktyczny Sąd ustalił w oparciu o dowody z dokumentów znajdujących się w aktach sprawy, [...] Sądu Rejonowego w. T., a także uzupełniająco o zeznania powoda i matki małoletniego pozwanego. [... S Sąd w pełni dał wiarę dowodom w postaci dokumentów $[\ldots]$

[...] Sąd miał na uwadze fakt, że każda ze stron przedstawiała wiele okoliczności w sposób jak najbardziej korzystny dla siebie. [... ] Natomiast Sąd nie dał wiary zeznaniom matki pozwanego w pozostałej ich części...... [...]

Reasumując, od zakończenia poprzedniego postępowania doszło do istotnej zmiany stosunków stanowiącej warunek zmiany wysokości alimentów [...] $\underline{\mathrm{W} \text { związku }}$ z powyższym, Sad doszedł do wniosku, iż powód obecnie jest w stanie płacić kwotę 400 zł miesięcznie na syna, ponieważ mieści się ona w jego możliwościach zarobkowych i majątkowych. [...]

Odrzucenie zarzutów pozwanego i odwotanie się do przepisów prawnych (Le rejet des prétentions et des moyens du demandeur et le visa légal)

Mając powyższe na uwadze, na mocy art. 138 kro, Sąd Rejonowy w. T. uwzględnił powództwo w części i obniżył z dniem 1.02.2016 r. rentę alimentacyjną R.B. względem mał. O.B. (1) [...] Natomiast w pozostałej części powództwo oddalił, o czym orzeczono jak w punkcie II wyroku. [... Rygor natychmiastowej wykonalności nadano wyrokowi z urzędu w trybie art. $333 \$ 1$ pkt 1 kpc, o czym orzeczono w punkcie V sentencji wyroku.

Źródło: III RC 696/15 wyrok z uzasadnieniem Sądu Okręgowego w Toruniu z dnia 1 marca 2016 roku, www.orzeczenia.ms.gov.pl (dostęp: 6.02.2020).

Z porównania makrostruktur wyroków polskich i francuskich wyraźnie widać, iż mimo wielu podobieństw, struktury orzeczeń sądowych w Polsce i we Francji znacznie się różnią. Ich sposób formułowania, wprowadzania argumentacji, a zwłaszcza kolejność poszczególnych elementów jest odmienna.

\section{Zakończenie}

Jak wynika z zaprezentowanej analizy kontrastywnej, polskie i francuskie orzeczenia mają skonwencjonalizowaną strukturę, zawierają podobne elementy, ale w układzie i kolejności podawanych informacji rysują się między nimi wyraźne rozbieżności. Poza tym większość wyrażeń zawartych w orzeczeniach 
to albo skostniałe wyrażenia, albo terminy, które posiadają szczególne właśnie w tym kontekście znaczenie, które najłatwiej jest ustalić, opierając się na tekstach porównywalnych.

Przeprowadzona analiza makrostruktury tekstów porównywalnych orzeczeń pokazuje również, jak istotne jest ich znaczenie w procesie tłumaczenia. Teksty porównywalne są nie tylko wiarygodnym źródłem informacji terminologicznej, tekstowo-normatywnej, ale dzięki temu, że są zanurzone w odpowiednim kontekście stanowią cenne źródło ekwiwalentów konotacyjnych (konotatów formalno-tekstowych właściwych dla tekstów prawnych zanurzonych w różnych systemach prawa). Można w tym miejscu przytoczyć terminy: Par ces motifs... („Z powyższych względów...”), Sur la recevabilité des attestations ... („W kwestii dopuszczalności poświadczeń świadków...”), dla których trudno ustalić ekwiwalenty w oparciu o dostępne słowniki, a które o wiele łatwiej ustalić, korzystając z tekstów porównywalnych. Przeprowadzone badania kontrastywne mogą przyczynić się do lepszego zrozumienia struktur analizowanego języka prawniczego praktyki orzeczniczej oraz struktury graficznej tekstów sądowych, a w konsekwencji wypracowania odpowiedniej dla tych tekstów strategii translatorskiej.

Niniejszy artykuł daje jedynie wyobrażenie o złożoności tematu i sygnalizuje problemy związane z tłumaczeniem makrostruktury orzeczeń sądowych w omawianej parze językowej. Opracowanie to nie wyczerpuje poruszanych zagadnień, niemniej stanowi przyczynek do głębszego zbadania makrostruktury wyroków polskich i francuskich.

\section{Bibliografia}

Castillo-Wyszogrodzka S. (2015), Uzasadnienia decyzji stosowania prawa w systemie francuskim, [w:] I. Rzucidło-Grochowska, M. Grochowski (red.), Uzasadnienia decyzji stosowania prawa, Warszawa, s. 481-499.

Cornu G. (2005), Linguistique juridique, Paris.

David R. (2002), Les grands systèmes de droit conteporains, Paris.

Delisle J. (2006), Terminologia tlumaczenia (przekład i adaptacja T. Tomaszkiewicz), Poznań.

Dolecki H. (2006), Postępowanie cywilne. Zarys wykładu, Warszawa.

Flöter-Durr M., Nowak-Korcz P. (2018), Analyse contrastive des textes de decisions judiciaires en la langue française, allemande et polonaise (referat wygłoszony na konferencji „13th Conference on Legal Translation Court Interpreting and Comparative Legilinguistics" w dniach 13-15 lipca 2018 na UAM w Poznaniu). 
Gudowski J. (2015), Uzasadnienie orzeczeń sądu najwyższego w sprawach cywil-

nych, [w:] I. Rzucidło-Grochowska, M. Grochowski (red.), Uzasadnienia decyzji stosowania prawa, Warszawa, s. 239-265.

Jopek-Bosiacka A. (2006), Przekład prawny i sadowy, Warszawa.

Kierzkowska D. (2002), Ttumaczenie prawnicze, Warszawa.

Krzysztoforska-Weisswasser Z. (1995), Wykorzystanie tekstów paralelnych przy thumaczeniu wyroków w procesie cywilnym, [w: ] Lingua Legis, http://www. translegis.com.pl/1l_archiwum/LL_2_6.pdf (dostęp: 6.02.2020).

Kubacki A.D. (2013), Teksty paralelne jako narzędzie pomocnicze przy sporzadzaniu tłumaczeń (specjalistycznych), [w:] A. Matulewska (red.), „Comparative Legilinguistics. International Journal for Legal Communication”, t. 13, s. 145-157.

Lizisowa M.T. (2013), Metody badań języka prawnego wobec ontologicznej natury prawa, [w: ] A. Matulewska (red.), „Comparative Legilinguistics. International Journal for Legal Communication”, t. 14, s. 21-46.

Lizisowa M.T. (2016), Komunikacyjna teoria języka prawnego, Poznań.

Machowska A., Wojtyczek K. (2004), Prawo francuskie, t. 1, Warszawa.

Matulewska A. (2010), Teksty paralelne a ustalanie konotatów i denotatów na potrzeby przekładu polsko-angielskiego, [w: J. Bańczerowski (red.) „Comparative Legilinguistics. International or Legal Communication”, t. 3, s. $55-68$.

Studzińska J., Cioch P. (2017), Postępowanie Cywilne, Warszawa.

Šarčević S. (2000), New Approach to Legal Translation, The Hague.

Zieliński M. (1999), Języki prawne i prawnicze, [w:] W. Pisarek (red.), Polszczyzna 2000: orędzie o stanie języka na przełomie tysiącleci, Kraków, s. 50-74.

Żołnierczyk D. (1995), Analiza przekładu tekstu wyroku sądowego z języka francuskiego na polski, [w:] Lingua Legis, http://www.translegis.com.pl/ 1l_archiwum/LL_2_8.pdf (dostęp: 6.02.2020).

Paulina Nowak-Korcz

\title{
MACROSTRUCTURE OF THE TEXTS OF COURT DECISIONS ON THE EXAMPLE OF POLISH AND FRENCH JUDGMENTS
}

\author{
(Summary)
}

This article concerns the comparative analysis of Polish and French Civil Court judicial decisions. Although the analyzed texts of judicial decisions are rooted in the culture of civil law and feature many similarities between the systems of Polish and French laws, both Polish and French judgments differ at the level of the global, graphic structure of texts. The article discusses the macrostructure of Polish and French judgments and their importance in the translation 
process. Next, selected problems emerging during their translation are presented in order to familiarize translators and interpreters with difficulties arising from the specific style and form of civil law judgments. The study is based on the analysis of comparable texts, as well as the model of pragmatic translation of legal terms proposed by Kierzkowska (2002). In addition, it is based on empirical observations of expressions and structures typical of Polish and French judgments. The author also emphasizes the special role of comparable texts in specialised translation and advocates the need to distinguish comparable and parallel texts.

Key words: judicial decision, judgment, comparable texts, macrostructure, ratio decidendi 